\title{
DISTINÇÃO E DIVULGAÇÃO: A CIVILIDADE E SEUS LIVROS
}

\section{DISTINCTION AND DISSEMINATION: CIVILITY AND HIS BOOKS}

João Vinicius Bobek ${ }^{1}$

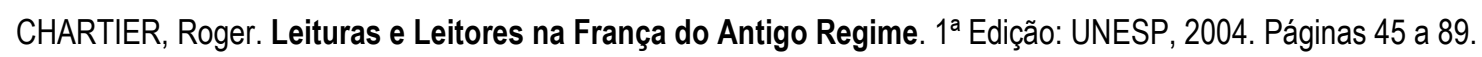

Palavras-chaves: discursos historiográficos; leitura; Antigo Regime Francês.

Keywords: historiographical discourses, reading, French Ancien Regime.

Roger Chartier historiador francês vinculado à atual historiografia da Escola de Annales, onde trabalha sobre a história do livro, da edição e da leitura, e que nesta obra apresenta oito ensaios que constituem uma história cultural em busca de textos, crenças e gestos aptos a caracterizar a cultura popular tal como ela existia na sociedade francesa entre a Idade Média e a Revolução Francesa. $O$ intelectual francês mostra que a cultura escrita influencia mesmo àqueles que não produzem ou lêem textos, mas interagem com eles. Ao revisitar a chamada Biblioteca Azul, coleção de livros acessíveis vendidos por ambulantes (romances de cavalaria, contos de fada, livros de devoção), além de documentos próprios da chamada "religião popular" e textos sobre temas que se dirigem a um público geral, como a cultura folclórica, o autor enfoca as tênues fronteiras entre a chamada cultura erudita e a popular, mostrando como se ligam duas histórias: da leitura e dos objetos de leitura.

Assim sendo Chartier reforça o plural do plural de "civilidades", que remete aos usos e intercâmbios de um código de polidez reconhecido por uma sociedade distinta, fazendo menção a Erasmo que rejeita os modelos aristocráticos da época pregando que a civilidade deveria ser uma instrução de um grupo moralizador, determinado, e deveria começar pelas crianças fazendo do aprendizado escolar a primeira instrução. $O$ autor também indica, sempre citando autores como Courtin, que a civilidade pode ser uma virtude cristã, a caridade, pois deve ser uma questão de cada um, diferenciando o Homem do Animal, distinguido na sua execução em tantos comportamentos convenientes a cada estado ou situação. Em decorrência desses conceitos, a partir do século XVII, a noção de civilidade ganha um sentido ambíguo, pois sua função é designar a conduta histórica dos príncipes de tragédia, pois segundo Toussaint, a civilidade torna-se "um cerimonial de conven-

\footnotetext{
1 Professor Especialista formado em Licenciatura em História pela UEPG e Egresso do Projeto: Educação, Cultura e Diversidade Cultural: uma inclusão necessária. Sub-programa do Projeto Universidade sem Fronteiras.
} 
ção", dando origem a uma polidez devida aos príncipes, sendo muitas vezes uma aparência ou uma máscara que disfarça e engana. Assim nesse contexto, o conceito de civilidade está situado no próprio centro da tensão entre o parecer e o ser que define a sensibilidade e a etiqueta barroca.

Sendo Roger Chartier discípulo da Escola de Annales ${ }^{2}$ percebe-se na compreensão do seu texto um intercâmbio entre a História Cultural ${ }^{3} \mathrm{e}$ a Antropologia, pois ele menciona Jean-Baptiste de La Salle para citar que este pensador abrange a civilidade tida honesta e piedosa como conveniência social. Portanto nessa teoria, a civilidade se afasta do uso aristocrático para constituir-se num controle permanente e geral de todas as condutas, sendo um modelo eficaz de comportamento das elites nas camadas inferiores.

A partir do século XVIII, a noção de civilidade conhece um duplo e contraditório destino, segundo Chartier. Ela permite aos humildes compreender o código de comportamentos, sendo que ensinada ao povo, a polidez se vê ao mesmo tempo desvalorizada aos olhos da elite que em contrapartida não exige nenhuma autenticidade de sentimento, sanciona a ruptura admitida e contraditória. Para Jacourt a civilidade foi imposta a inúmeros indivíduos e por isso perdeu seu valor de distinção, considerando que foi colocada a maioria e se tornou uma norma para as condutas populares.

Para fundar uma civilidade republicana, o articulista, juntamente com outros pensadores sugerem uma ruptura radical com a educação tradicional, já que a repetição dos gestos considerados convenientes é idealmente substituída pela aprendizagem de virtudes que conseguirão sempre expressar-se numa linguagem moral resultando numa instrução moral. Para 0 autor as novas obrigações dessa civilidade republicana não devem se regulamentar-se pelas diferenças de condição ou posição, pois se apóia na liberdade, conforme a igualdade. A civilidade refundida deve reconciliar enfim as qualidades da alma e as aparências exteriores, sendo nítida a recusa das formalidades antigas, pois essa abdicação à etiqueta tradicional encontra-se manifesta na esfera política.

Finalizando esse capítulo de sua obra, que deixa evidente os conceitos de polidez e civilidade, Chartier, deixa claro que a partir do século XIX, a civilidade pode ser definida como um conjunto de regras que tornam agradáveis e fáceis às relações dos homens entre si, podendo ser entendida como um código de boas maneiras necessárias na sociedade, sendo constituída e fixada por todo esse século, a identificação da civilidade com a conveniência burguesa.

\footnotetext{
2 Incorpora métodos das Ciências Sociais à História. Encontramos neste movimento, certa unidade em sua composição, mas não uma homogeneidade. Sendo como um conjunto de estratégias, uma nova sensibilidade, uma atividade que de fato mostra-se pouco preocupada com definições teóricas.

${ }^{3}$ Frequentemente combina as abordagens da antropologia e da história para olhar para as tradições da cultura popular e interpretações culturais da experiência histórica. Ela se sobrepõe, em sua abordagem, ao movimento francês da história das mentalidades e à chamada Nova História.
} 
Portanto pode-se comprovar que entre os séculos XVI e XIX, a noção de civilidade sofre mudanças e apanha um enfraquecimento. Deste modo apesar das tentativas de reformulá-la, a noção perde um pouco da teoria ético-cristã para significar apenas a aprendizagem das maneiras convenientes na vida das relações da sociedade, questionando assim, a diferença entre cultura popular e erudita, para obter-se a definição de tradição popular simplesmente como oposição à cultura erudita. Roger discute como diversos textos franceses desses séculos, que atravessam as fronteiras sociais entre clero, nobreza e Terceiro Estado. $O$ historiador francês mostra assim a influência exercida pelo documento escrito mesmo entre os que não estão familiarizados com o livro e reconstitui em sua complexidade a comunicação cultural entre os homens do Antigo Regime.

Destarte para Roger Chartier, interpretam-se os artefatos, objetos históricos de análise, num campo onde se cruzam duas linhas: uma vertical, ou diacrônica, pela qual o historiador estabelece a relação de um texto ou de um sistema de pensamento com manifestações anteriores no mesmo ramo de atividade cultural; a outra é horizontal ou sincrônica, e através dela determina a relação do objeto cultural com o que vai surgindo noutros aspectos de uma cultura.

Pode-se afirmar que o historiador tem uma posição bastante clara e comunga com a nova maneira de fazer história iniciada pela escola dos Annales: "Desembaraçando-se das etiquetas que pretendendo identificar os pensamentos antigos, os marcaram na realidade, a tarefa dos historiadores do movimento intelectual", como escreve 4Lucien Febvre, é acima de tudo reencontrar a originalidade irredutível a qualquer definição à priori, de cada sistema de pensamento, na sua complexidade e nas suas mudanças.

A dicotomia esquemática proposta pelos historiadores românticos não tem lugar dentro deste novo conceito de fazer história. Assim como qualquer outro exemplo de oposição rígida torna-se ridículo em face desta nova concepção dos historiadores dos Annales; concepção reafirmada pela atual definição de História Cultural que coloca a posição do historiador perante os artefatos históricos. Tal modo, através desta obra de Chartier, é possível trabalhar com os discursos historiográficos, realizando uma análise da passagem da leitura extensiva à intensiva, para assim poder abordar com destaque os aspectos da leitura como formação da identidade cultural intelectual francesa, para futuramente adquirir noções de abordagens de tópicos sociais do Antigo Regime.

\section{Resenha recebida em: 09/04/2010 \\ Aceita para publicação em: 23/05/2010}

\footnotetext{
4 Lucien Febvre historiador francês, cofundador da chamada "Escola dos Annales" e idealizou juntamente com Marc Bloch, a revista de História em 1929, chamada "Revue des Annales".
} 